\title{
A suspicious lump of unexpected origin
}

\author{
Philip James Joseph Herrod, Prashanth Shetty, Neil Martin
}

Department of Respiratory Medicine, University Hospitals of Leicester NHS Trust, Leicester, UK

\section{Correspondence to} Dr Philip James Joseph Herrod, pherrod@nhs.net
To cite: Herrod PJJ, Shetty P, Martin N. BMJ Case Rep Published online: [please include Day Month Year] doi:10.1136/bcr-2013009345

\section{DESCRIPTION}

An 86-year-old man presented to the acute medical take with a 1 day history of sharp right-sided chest pain and increasing shortness of breath. He was a current smoker with a 50-pack year smoking history and his medical history included chronic obstructive pulmonary disease, ischaemic heart disease, hypertension and Parkinson's disease. He also complained of a lump on his right upper chest that had been present for 3 months. This had slowly increased in size and was painless. During this time he had consulted several general practitioners who had prescribed him antibiotics and offered excision on a minor operating list.

The lump on presentation to the take is displayed in figure 1. This was a single, painless, firm, mobile, reddish, nodular skin lesion measuring about $4-5 \mathrm{~cm}$ in diameter and depth. He was mildly tachycardiac otherwise physical examination was unremarkable. He was hypoxic with a $\mathrm{PaO}_{2}$ of $8.78 \mathrm{kPa}$ on air and had a raised $\mathrm{D}$-dimer. His plain chest radiograph is displayed in figure 2 and in view of his presentation a CT pulmonary angiogram was arranged to investigate a possible pulmonary embolism. As it was suspected that his lump was malignant, an urgent review by a dermatologist was arranged.

His CT revealed a large pancoast tumour at the right apex with invasion into his chest wall (figure 3 ). A separate nodule was found in his right lower lobe.



Figure 1 The lump on the patient's chest wall.

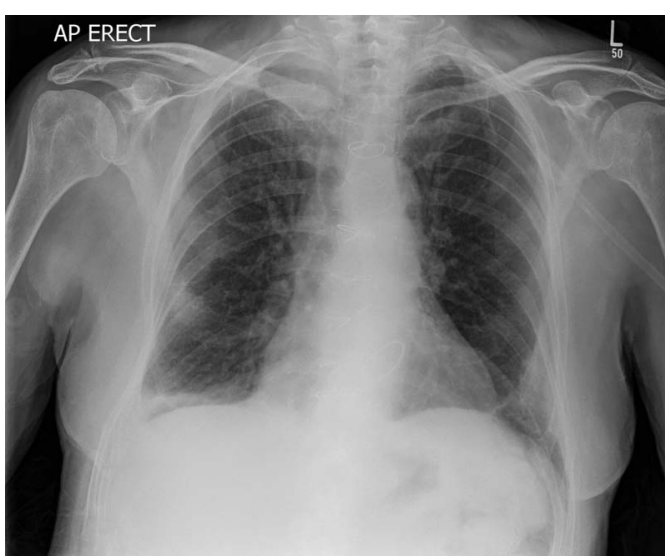

Figure 2 Plain chest radiograph.

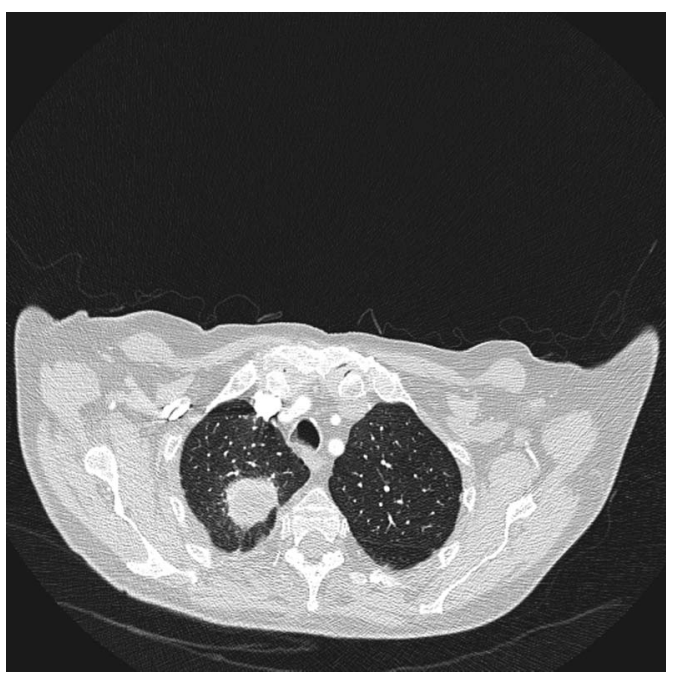

Figure 3 A CT slice showing a mass at the apex of the patient's right lung.

He subsequently underwent fine needle aspiration of the skin lump, cytology revealing metastatic nonsmall-cell carcinoma of the lung.

\section{Learning points}

- Skin metastases from the lung cancer are rare. ${ }^{1}$

- This is usually associated with a poor prognosis. $^{2}$

- Must be ruled out in patients with suspicious skin lesions and history of smoking or lung cancer.

Competing interests None.

Patient consent Obtained.

Provenance and peer review Not commissioned; externally peer reviewed. 


\section{REFERENCES}

1 Bobba R, Odem J, Doll D, et al. Skin metastases in non-small cell lung cancer. Am J Med Sci 2012;344:59-62.
2 Dhambri S, Zendah I, Ayadi-Kaddour A, et al. Cutaneous metastasis of lung carcinoma: a retrospective study of 12 cases. J Eur Acad Dermatol Venereol 2011;25:1104-7.

Copyright 2013 BMJ Publishing Group. All rights reserved. For permission to reuse any of this content visit http://group.bmj.com/group/rights-licensing/permissions.

BMJ Case Report Fellows may re-use this article for personal use and teaching without any further permission.

Become a Fellow of BMJ Case Reports today and you can:

- Submit as many cases as you like

- Enjoy fast sympathetic peer review and rapid publication of accepted articles

- Access all the published articles

- Re-use any of the published material for personal use and teaching without further permission

For information on Institutional Fellowships contact consortiasales@bmjgroup.com

Visit casereports.bmj.com for more articles like this and to become a Fellow 